\title{
Mortality of game mammals caused by an extreme flooding event in south-western Poland
}

\author{
Andrzej Wuczyński • Zbigniew Jakubiec
}

Received: 20 November 2012/ Accepted: 3 April 2013/Published online: 17 April 2013

(C) The Author(s) 2013. This article is published with open access at Springerlink.com

\begin{abstract}
We examine mortality in five terrestrial species of game animals resulting from an extreme flood event in Central Europe in July 1997. We present species-specific mortality rates and collate them with local abundances to show the susceptibilities of the different species to flood mortality. We also compare mortality rates in areas inundated by the main river and by its tributaries. Data were collected in the catchment area of the Odra River, south-western Poland. Mortality was estimated by surveying for drowned animals in flooded areas of 50 hunting districts $\left(2,876 \mathrm{~km}^{2}\right)$. Total mortality amounted to 3,613 individuals, mostly of roe deer Capreolus capreolus and brown hare Lepus europaeus. Relative to estimates of abundance, mortality was disproportionately high in hares. Drownings of roe deer and wild boar, Sus scrofa were proportional to local abundance. Young individuals were particularly affected. Mortality was low in foxes, Vulpes vulpes, and red deer, Cervus elaphus. The mortality rate increased with the proportion of area flooded and the duration of flooding and was four times higher along the Odra River than along its tributaries. Our data specify, for the first time, direct losses in wild, large animals in response to an extreme flood event. Despite high overall losses, negative long-term effects on populations seemed unlikely. Nevertheless, to lessen the impact, river management focused primarily on human safety should also integrate the needs of wildlife.
\end{abstract}

Keywords Flood disturbance $\cdot$ Natural hazards - Mortality rate $\cdot$ Population dynamics · River management $\cdot$ Central Europe

\section{Introduction}

Disastrous natural phenomena are predicted to have a profound impact on wild animals (Parmesan et al. 2000; Holmgren et al. 2006). Catastrophic events cause dramatic shortterm population declines or local extinctions, either from direct mortality or habitat

\footnotetext{
A. Wuczyński $(\bowtie) \cdot$ Z. Jakubiec Institute of Nature Conservation, Polish Academy of Sciences, Lower-Silesian Field Station, Podwale 75, 50-449 Wrocław, Poland e-mail: a.wuczynski@pwr.wroc.pl
} 
destruction. Within a selected taxonomic group like mammals, the level of disruption will depend on species-specific behaviour, morphology and life history characteristics (Bunn and Arthington 2002; Robinson et al. 2002; Lytle and Poff 2004). Each individual will experience a risk of death or displacement which is determined by the interaction of the event parameters, the behavioural and physical attributes of the animal and habitat characteristics. However, these specific outcomes and the overall influence of stochastic disasters on animals are extremely difficult to document. Catastrophic disturbances are rare, ephemeral and unpredictable, and a systematic study is difficult to design. To date, most studies have evaluated the effects of ecological catastrophes indirectly, via changes in population dynamics. Direct losses are less understood because they can rarely be observed, disturbed areas are not accessible for a long time and dead animals disappear quickly, being washed away by flood waters, burnt in fires or covered by volcanic ash (Welbergen et al. 2008; McKechnie and Wolf 2009; Tryjanowski et al. 2009).

Disastrous floods have recently been recognized as a major hazard in many parts of the world. Riverine flooding may affect vast areas, occur with high and increasing frequency (Kundzewicz and Schellnhuber 2004; Palmer et al. 2008) and cause dramatic damage in human-dominated habitats (Jonkman 2008). Floods affect also animal populations, although the negative influence on wildlife is not so obvious. Post-flood diversification of habitats can offset high direct mortality, and many taxa may actually benefit from flooding (Bennetts et al. 2002; Ballinger et al. 2005; Lada et al. 2007). Vertebrates associated with aquatic and riparian habitats are usually resistant to river discharge and inundation, as confirmed by studies on beavers (Breck et al. 2001), birds (Poiani 2006), amphibians (Bateman et al. 2008) or fish (Humphries et al. 1999; Franssen et al. 2006). In contrast, severe losses can be expected in terrestrial animals in flooded areas.

Unfortunately, unlike the well-studied impact of floods on small mammals (Andersen et al. 2000; Williams et al. 2001; Jacob 2003; Thibault and Brown 2008), little is known about the influence of floods on large vertebrates (Heinen and Singh 2001; Profus 2002). There is a paucity of equivalent data collected over large areas on large animals. Nor have comparisons been made for losses of wild mammals caused by differing degrees of flooding of rivers, large and small.

In July 1997, Central Europe experienced a flood believed to be the most extensive on record, in both hydrological and economic terms (Kundzewicz et al. 1999). Hundreds of square kilometres in the middle and upper Odra/Oder and Wisła/Vistula rivers were inundated, with a strong impact on humans, habitats and animal communities. The influence of this catastrophic event on animals was only partially recognized (Ważna and Gabryś 1998; Ogielska et al. 1999; Jakubiec and Wuczyński 2002; Profus 2002; Tryjanowski et al. 2009). Unfortunately, there is no thorough understanding of the global impact of this flood on any taxa, particularly because of the unpredictability of the disruption of such a magnitude and the lack of analysis of pre-flood data.

Hunting statistics are a valuable source of information due to the temporal continuity of data collection, standard methodology, inclusion of several species, and coverage of large and constant areas (Ericsson and Wallin 1999). The availability of censuses of game populations in pre- and post-flood periods within identical spatial units can be considered the basis for a serendipitous large-scale investigation. The disastrous scale of the event in 1997 in south-western Poland triggered several field activities immediately after the flood to assess game mortality.

In this study, we have taken the opportunity provided by archival data to examine the effects of the flood on local game populations. Specifically, the aims of the study were (1) to present the magnitude of flood-related losses in wild mammals, (2) to compare the 
susceptibility of selected mammal species to flood mortality and (3) to compare the mortality in areas inundated by the main river (Odra River) and by its tributaries. We also discuss the possible long-term influence of flood mortality on populations of the species studied.

\section{Methods}

\subsection{Study area}

Data were collected in the catchment area of the Odra River, one of Europe's great rivers, with a length of $871 \mathrm{~km}$. The section studied, $\sim 220 \mathrm{~km}$ long, is situated in the middle course of the river, between Kędzierzyn-Koźle and Ścinawa (south-western Poland). The section has been regulated, embanked and navigable since the nineteenth century. The adjoining lowlands are dominated by intensive agricultural landscapes interspersed with strongly fragmented woodlands.

The study was carried out in 50 hunting districts, the basic units in our analysis, with an area of $2,876 \mathrm{~km}^{2}$. Twenty-eight districts $\left(1,493 \mathrm{~km}^{2}\right)$ were situated in the Odra River valley, and the other 22 districts $\left(1,383 \mathrm{~km}^{2}\right)$ were situated along 12 tributaries of the main channel (Fig. 1). Districts situated along the Odra River (ORD) were smaller and more wooded than the districts adjoining tributaries (TRD), but the differences were not significant (Table 1). In ORD the proportion of area flooded was three times greater, and the period of inundation was twice as long as in TRD. Overall, more than $30 \%$ of the study area was inundated.

\subsection{Flood characteristics}

The flood started in the study area on 7 July 1997 and lasted until the end of the month (with two rainfall peaks). It was generated by exceptionally heavy rainfall between 4 and 10 July. The rainfall constituted 150-250 \% (locally more than $300 \%$ ) of a month's mean rainfall and $20 \%$ (locally up to $40 \%$ ) of a year's mean. A second, slightly smaller rainfall peak occurred between 17 and 22 July (Dubicki et al. 1999; Kundzewicz et al. 1999). The maximum flows on the Odra River in Wrocław, which is within our study area, amounted to $3,640 \mathrm{~m}^{3} / \mathrm{s}$ and were 25 times greater than the average annual flow $\left(145 \mathrm{~m}^{3} / \mathrm{s}\right)$. The depth of flood waves outside the river bed was several metres, and water stagnation lasted up to 3 months in lower locations. The Odra River has experienced tens of floods described as 'great' since the thirteenth century, but usable quantitative data have been known only since the nineteenth century. On their basis, the July 1997 flood was the greatest of all documented (Dubicki et al. 1999; Kundzewicz et al. 1999).

\subsection{Source of data on flood mortality}

To evaluate the losses in game mammals within each hunting district, we used results from surveys carried out by hunters as organized by the regional boards of the Polish Hunting Association. These were implemented immediately after the water had receded, at the end of July and early August 1997. Records were taken of the number of dead animals found, and the estimate of total mortality was made by hunters on this basis. The totals given 


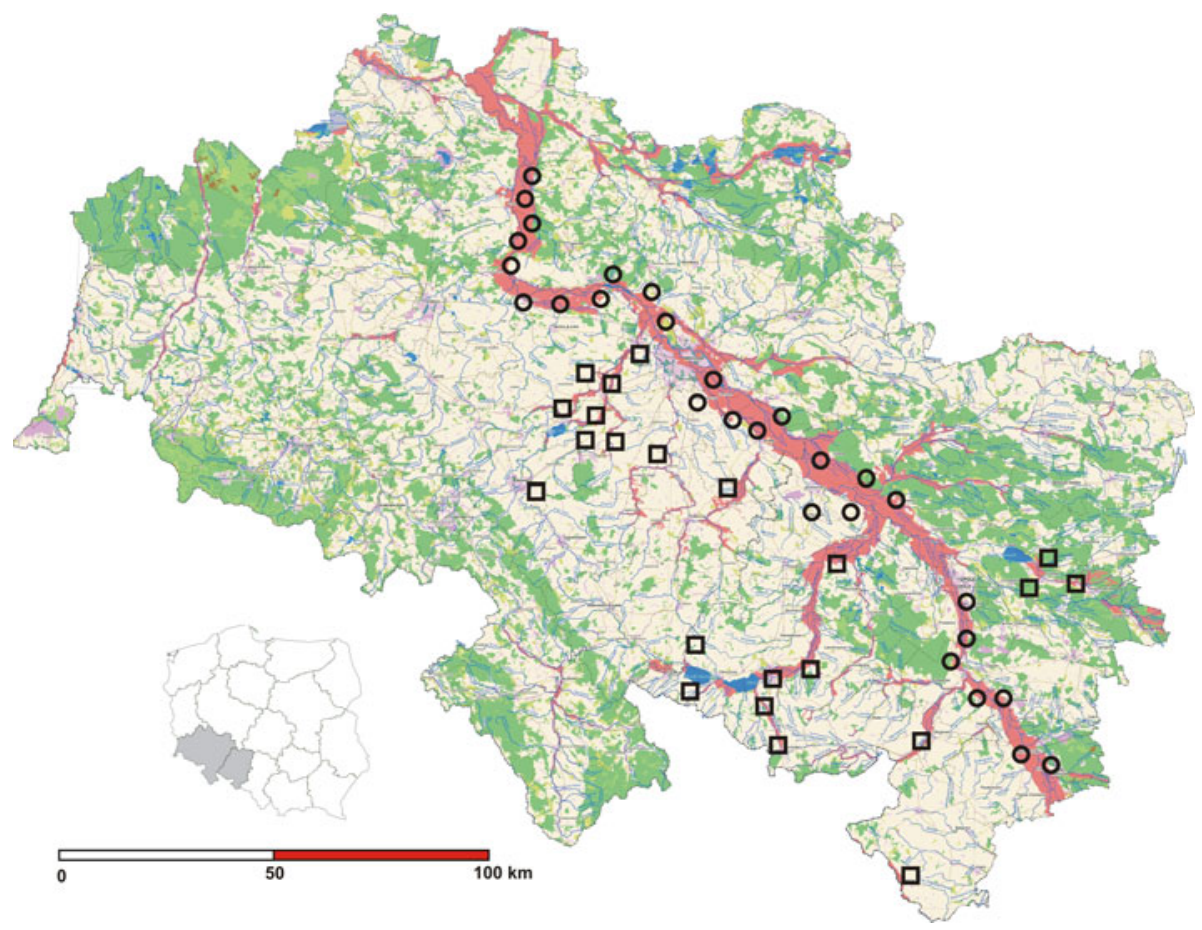

Fig. 1 Location of the studied hunting districts adjoining the Odra River (circles) and the tributaries (squares), against a background of the main topographical features of the two administrative units of Poland (Dolnośląskie Province and Opolskie Province) where the survey was conducted. The extent of the July 1997 flood is also presented

Table 1 Characteristics of the studied hunting districts

\begin{tabular}{llcc}
\hline & All districts & Odra River & Tributaries \\
\hline No. of districts & 50 & 28 & 22 \\
Area of district (ha) & $5,752.5 \pm 1,734.4(50)$ & $5,331.8 \pm 1,428.8(28)$ & $6,287.9 \pm 1,964.3(22)$ \\
Wooded area (\%) & $23.5 \pm 21.6(25)$ & $28.1 \pm 24.7(13)$ & $18.4 \pm 17.2(12)$ \\
Flooded area (\%) & $31.5 \pm 26.9(47)$ & $\mathbf{4 4 . 4} \pm \mathbf{2 7 . 3} *(27)$ & $\mathbf{1 4 . 1} \pm \mathbf{1 3 . 5 * * ( 2 0 )}$ \\
Days of inundation & $13.7 \pm 8.6(15)$ & $\mathbf{2 0 . 2} \pm \mathbf{8 . 8} *(6)$ & $\mathbf{9 . 3} \pm \mathbf{5 . 2} *(9)$ \\
\hline
\end{tabular}

The values are mean $\pm \mathrm{SD}$, calculated on the number of districts for which data were available, provided in parentheses

Significant differences are marked bold (Mann-Whitney $U$ test, ${ }^{*} P<0.001,{ }^{*} P<0.05$ )

below are the sums of the estimates. Some records listed the age and gender of drowned animals, as well as the area and period of inundation.

\subsection{Selection of species}

Deaths of eight species of game mammals were recorded: roe deer Capreolus capreolus, red deer Cervus elaphus, fallow deer Dama dama, wild boar Sus scrofa, fox Vulpes vulpes, badger Meles meles, brown hare Lepus europaeus and European rabbit Oryctolagus 
cuniculus. In our analyses, we omitted $D$. dama and $O$. cuniculus due to their highly localized distribution, and $M$. meles due to incomplete data. Estimated losses in game birds provided in some districts were also disregarded. In the end, we analysed the impact of the flood on five species of game mammals which were common in the study area, and whose recorded mortality rate allowed for statistical evaluation. None of these species was connected with river valleys as their primary habitat.

\subsection{Susceptibility to flood mortality}

We expected that the five species would differ in their susceptibility to flood-induced mortality. To check this expectation, we compared the mortality in particular species with their local abundance. The comparison was restricted to the 38 hunting districts for which data on both mortality and pre-flood abundance were available (28 ORD and 10 TRD, $1,982 \mathrm{~km}^{2}$ in total). Local abundance was estimated during the game census carried out each March by hunters and foresters to plan game management in Poland. The estimate was based on standard methods of year-round observation of animals in hunting districts (Fruziński 2002). The alternative method of counting snow tracks (Pucek et al. 1975) commonly used in other parts of the country can rarely be used in south-western Poland because of snowless winters.

We compared the mortality in particular species with their pre-flood abundance in March and July 1997. Since both analyses gave similar results, we present only the comparison with the July data, that is, when the flood happened. To obtain these data, we estimated the increase in population size from March as a result of the proportion of females breeding, birth rates and mortality rates of young based on other research in Poland; the following population growth rates were estimated: C. capreolus-1.8 (Pielowski 1988), S. scrofa-1.9 (Fruziński 1992), V. vulpes-2.5 (Goszczyński 1995), C. elaphus-1.3 (Bobek et al. 1992), L. europaeus-1.5 (Krupka 1989). The number of females in the population of $C$. capreolus and $C$. elaphus was determined during the counts. The proportion of females in S. scrofa, L. europaeus and V. vulpes was assumed to be $50 \%$.

\subsection{Statistical analyses}

Sample sizes in our analyses were restricted by the availability of archive data. In many hunting districts, zero values were noted (no mortality), particularly for species with low overall mortality. Consequently, most variables had skewed distributions, and we were obliged to use nonparametric tests. The Spearman rank correlation coefficient was used to test the relationships between total mortality and the flood parameters, that is, area and duration of inundation. The differences in mortality between the districts adjoining the main river and the tributaries were tested with the Mann-Whitney $U$ test, chi-squared test of independence or Fisher's exact test. Flood mortality and pre-flood abundance in particular species were compared based on proportions. To determine significance, we used the chi-squared test of goodness-of-fit with species abundance treated as the expected value, and species mortality treated as the observed value. Additionally, we calculated the Jacobs selectivity index (index $D$ in Jacobs (1974), usually used in habitat selection studies) to evaluate synthetically the susceptibility of the studied mammals to flood mortality. The Jacobs index was calculated according to the formula $D=(r-p) /$ $(r+p-2 r p)$, where $r=$ the proportion of mortality in particular species, and $p=$ the proportion of abundance in particular species compared to the total abundance of the five 


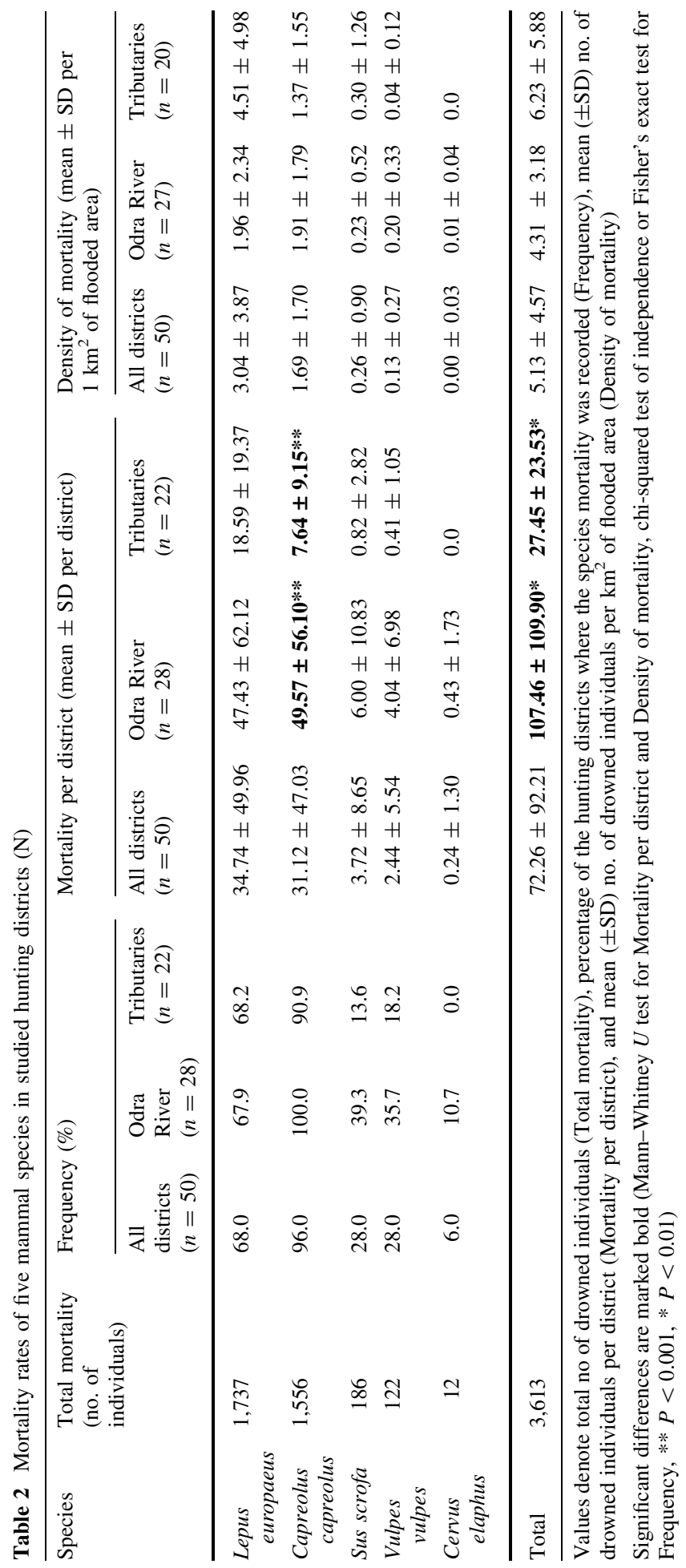


species under study. $D$ varies from -1 (lack of susceptibility to flood-related mortality) to +1 (strong susceptibility), and values close to zero indicate that the species' mortality is in proportion to its abundance. The probability of $P<0.05$ was assumed as statistically significant. The statistical calculations were performed with STATISTICA for Windows (StatSoft Inc. 2010).

\section{Results}

\subsection{Magnitude of mortality}

Total mortality amounted to 3,613 individuals in 50 hunting districts. The density of mortality was 5.13 individuals per $\mathrm{km}^{2}$ of flooded area (Table 2). More than $90 \%$ of dead animals were L. europaeus and C. capreolus. Even in these two species, the mortality was unequally distributed among districts, probably reflecting differences in flood severity. Drownings of $C$. capreolus were noted in most districts ( $96 \%$ ), whereas drownings of $L$. europaeus occurred only in $68 \%$ of districts. The mortality rate (all species combined) increased with the proportion of area flooded $\left(r_{s}=0.51, d f=47, t=4.03, P<0.001\right)$, and the duration of flooding $\left(r_{s}=0.55, d f=15, t=2.38, P<0.05\right)$. Mortality affected an average 2.3 species per hunting district; mortality in all five species was reported from one district only. Drownings were mostly of young individuals; based on ten districts for which quantitative data on the age of drowned animals were available, young constituted 25 of $30 \mathrm{~S}$. scrofa recorded $(83 \%)$ and 33 of 44 C. capreolus $(75 \%)$. The other 11 of adult C. capreolus included nine females and two males.

\subsection{Susceptibility to flood mortality}

The highest mortality affected species which were most common in the study area, $C$. capreolus and L. europaeus. However, observed mortality significantly departed from expected results based on the relative abundance of particular species (chi-square $=627.8$, $d f=4, P<0.001)$. The Jacobs index confirmed differing susceptibility of the mammals studied to flood mortality (Fig. 2). The index revealed disproportionately high mortality in L. europaeus, low mortality in $V$. vulpes and C. elaphus, whereas the number of drownings of $C$. capreolus and $S$. scrofa was proportionate to their local abundance.
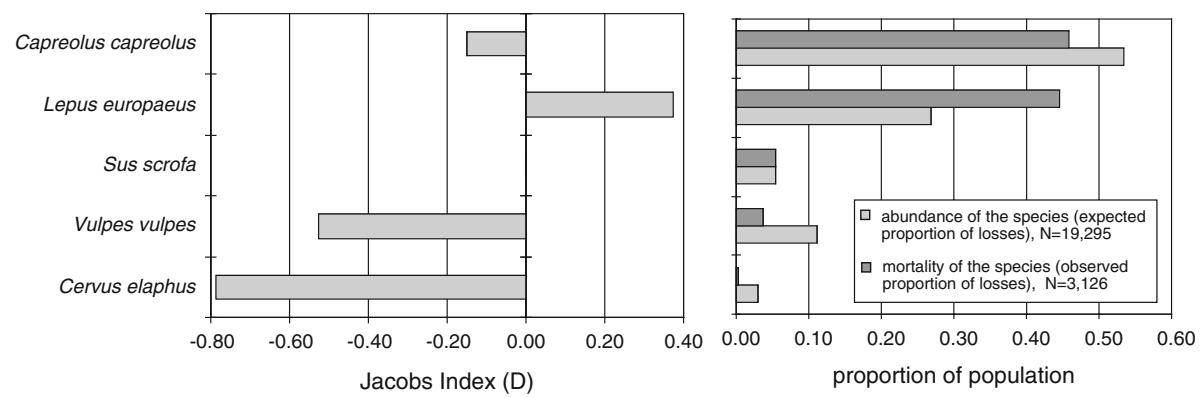

Fig. 2 Susceptibility of game mammals to flood-related mortality expressed by Jacobs D Index (left panel), and the relative abundance and relative mortality of particular species in the study area (right panel). Results obtained from 38 hunting districts for which data on both abundance and mortality were available 
3.3 Flood mortality in areas adjoining the main river and tributaries

Total mortality was four times higher in ORD than in TRD (Table 2). The highest, tenfold, difference related to $V$. vulpes and the lowest difference related to $C$. capreolus; however, only in the latter species was the difference significant. Mortality of $C$. elaphus was reported only in districts adjoining the Odra River. Densities of losses did not differ significantly between ORD and TRD, although in the case of L. europaeus, the value was more than twice as low in ORD as in TRD.

\section{Discussion}

\subsection{Magnitude of mortality}

The results of our study demonstrate a major, albeit short-term, impact of an extreme climate event on wild animals. Absolute numbers of drowned individuals were high $(>3,600)$, particularly in L. europaeus and C. capreolus, and most game species temporarily disappeared from affected floodplains. Anecdotal observations indicated that it is probable that some individuals could survive in floodplains by moving to higher locations. The families of $S$. scrofa survived the inundation period by staying on flood embankments that had become islands. $V$. vulpes were observed climbing up trees sticking out of the water. Despite these examples, it was emphasized that vast areas were covered with the deposits of sediments that hindered movement and restricted food availability. Consequently, during the first months after the water had receded (until October/November), the area of inundation was practically devoid of animals.

Assessment of the long-term influence of the flood on game populations is difficult because the dynamics of the population numbers is strongly regulated by harvest and/or release of game animals. Moreover, the census techniques can be inaccurate (Okarma and Tomek 2008). Nevertheless, it seems that the long-term effect of the flooding event in July 1997 on game mammals was insignificant. Despite high overall losses, only a small proportion of the numerous game population in this part of Europe was affected. Moreover, high movement abilities apparently allowed the studied species to resettle the abandoned areas quickly. To test these suppositions, we had previously compared the pre- and postflood game censuses in areas affected and not affected by the floods (Jakubiec and Wuczyński 2002). No long-term decreases in population size, nor deviations from the general regional trends were observed in the flooded areas. It confirms that wild species have life history strategies that buffer them from the negative effects of naturally recurring events, such as floods, and that conclusions drawn from the short-term effects can be misleading (Lytle and Poff 2004; Finkelstein et al. 2010; Gerisch et al. 2012).

We argue that the impact of floods and other natural disasters on wild populations should not be seen only from the perspective of changes in population size. Catastrophic events are forces able to change the social organization of many species and the way animals exploit their environment. Sudden removal of a large number of individuals initiates complex density-dependent processes which in turn influence the genetic make-up of the population (Newton 1998; Loveridge et al. 2006; Ranta et al. 2006). These processes are accompanied by severe habitat transformations modifying patterns of habitat use. For example, flooding events are responsible for delivering nutrients and detritus to the floodplain (Ward et al. 2002); thus, floods enhance biological productivity and food availability for animals. Heterogeneity of habitats caused by floods affects the dispersal of 
animals in the floodplain and shapes species-specific recolonization patterns (Wijnhoven et al. 2006). Anthony et al. (2003) recognized a group of insectivores and rodents associated with early successional vegetation produced by episodes of flooding and other disturbance in riparian zones. In the end, natural disasters have diverse functional consequences for populations, and it is crucial that we understand whether the long-term effect of these disturbances is advantageous or not for wildlife.

\subsection{Susceptibility to flood mortality}

None of the five mammals studied is riparian obligate nor a riparian-associated species sensu Anthony et al. (2003), with life history strategies that have evolved to inhabit the riparian zone and deal with altered flow. However, all these species comprise relatively big and highly mobile animals. They regularly use both wooded and agricultural landscapes, which prevent them from being trapped within their primary environment (e.g. forests) by rising floodwaters. Nevertheless, we noted diverse susceptibility to flooding in the mammals studied. The highest relative mortality rates, in L. europaeus, and the lowest mortality, in C. elaphus, suggest a relationship with body size. Dimensions of the animal seem to be crucial during the initial phase of the flood. Small animals (like L. europaeus) were less likely to survive the sudden strike of flood waves, particularly in the vicinity of places where the levees were broken. Slowly rising waters in the remaining area could also be critical for small animals if the waters blocked their retreat. Relatively, low mortality was revealed in $V$. vulpes, the second smallest of the studied species, but the mortality was probably underestimated. Many individuals were probably drowned in burrows, which could have had an effect on the low detectability of dead $V$. vulpes. For the same likely reason low losses concerned also $M$. meles, another burrowing carnivore occurring in the studied area (Jakubiec and Wuczyński 2002).

All the species studied are good swimmers which occasionally voluntarily swim (Yeager and Anderson 1944; Gittleman 1996). Drownings of these species are rarely recorded in usual situations (Peris and Morales 2004; García 2009). However, under exceptional conditions of disastrous floods, even the largest species can be affected. Observations of $S$. scrofa (see above) and other animals that were concentrated on the levees (Yeager and Anderson 1944; Stickel 1948) confirm that the ability to swim may not be sufficient to rescue. In July 1997 particularly high flow energy occurred in places where flood embankments were broken, resulted in high number of drowned animals found in the vicinity of these places. The death ensued there probably because of the overtaking by the sudden water rise outside the embanked area.

There was disproportionately high mortality among young animals as might be expected of small relative body size, low resistance and lack of experience (Heinen and Singh 2001; Welbergen et al. 2008). Along with the young, females could also die, as they tend to stay with their offspring even when floodwaters are rising (Pielowski 1988). Sex-biased mortality in $C$. capreolus was confirmed in our data; females predominated among adults noted. In this context, the timing of the flood was crucial. Summer floods generated by intensive precipitation are particularly common and destructive in Central Europe (Kundzewicz 2005). These events coincide with the reproduction period of many taxa. Therefore, summer floods cause severe losses in first-year individuals which predominate in many populations (Tryjanowski et al. 2009). In contrast, winter rainfall floods and spring snowmelt floods predominantly affect adults and full-grown young. Combined with a generally lower incidence in Central Europe, these floods do not generate such a high mortality in animal populations as summer floods. 
4.3 Flood mortality in areas adjoining the main river and tributaries

Differences in mortality between ORD and TRD corresponded with differences in flood severity and landscape structure. The percentage of areas flooded was four times bigger in ORD, as was the magnitude of mortality. Pronounced mortality of L. europaeus in TRD was connected with the predominance of cropland in these districts. In turn, higher amount of forests in the Odra River valley could have increased the losses of primarily forest species, C. elaphus and S. scrofa, in ORD. Common fencing of forest cultures probably contributed to the high mortality level. Dead C. capreolus were found hanging on wire nets used for fencing, probably pressed against them by the flowing water.

Differences in mortality between ORD and TRD were not significant when calculated per unit of flooded area. It suggests that the level of mortality is primarily shaped by the size of inundated areas, and the associated parameters (flooding duration or depth) are of secondary importance. Therefore, mild discharges which are less destructive in economic terms can also be disastrous for local animal populations, particularly for taxa of limited movement capabilities. High density of mortality revealed for L. europaeus in TRD suggests that local flooding episodes can be meaningful for several other taxa. Since these episodes are frequent, their total impact on animal communities can be no less important than the impact of rare but well-publicized floods described as catastrophes.

\section{Conclusion}

We specified quantitatively, for the first time, direct losses in wild, large animals over vast areas in response to a catastrophic flood. Data refer to a limited set of game mammals, though the findings may give some wider insight into the naturally functioning riverfloodplain ecosystems. River valleys represent areas of great ecological richness and diversity and are used by many species disproportionately higher than other areas (Tomiałojć 1993; Sabo et al. 2005). In the landscape context, river valleys act as ecological corridors allowing connectivity between suitable habitat fragments across the landscape (Jankowski and Świerkosz 1995; Ward et al. 2002). The corridor function is also provided for a range of mammals, including large species, especially when spatial cohesion of seminatural habitats (riparian forests, island) is preserved (Romanowski 2007). Riverine landscapes are also a product of disturbances that affect structure and function of these areas and the associated fauna, although understanding this impact still provides a major challenge for the future.

In modern times, the influence of natural disastrous phenomena on wildlife cannot be examined in isolation from human activity. River valleys have been substantially transformed (Schinegger et al. 2012) and have become inhabited by upland organisms not adopted to altered flow, but particularly vulnerable to extreme events. Our data refer to species which are numerous in Poland and elsewhere in Europe and not threatened. Rare and/or localized species may experience flood disturbance in a different way, so that the relative losses could be meaningful for their populations (Heinen and Singh 2001; Finkelstein et al. 2010). However, there is little evidence on the long-term effects of the natural disturbances on animal communities, in either a positive or negative sense (Tryjanowski et al. 2009). The ambiguity of the mechanisms responsible for these effects demands caution, but any mitigation actions should nevertheless consider the minimization of losses in biodiversity. Recent evidence is growing that management options focused primarily on human safety and water security should also integrate conservation issues 
(Poff et al. 2003; Vörösmarty et al. 2010). In large spatial scales (e.g. watersheds), many measures have been proposed to reach balance between ecological and human needs (Boon et al. 2000; Pedroli et al. 2002; Paredes-Arquiola et al. 2011). To lessen flood mortality in biological populations, proactive management interventions are particularly indicated (Palmer et al. 2008). Their general aim would be to restore the natural capacity of rivers, thus to reduce flood incidence, to absorb high flow energy and to truncate the peak flow. Local river management practices focused on wildlife also seem possible, for example fencing cultivated forests and roads should be abandoned in those parts of floodplains which are subject to frequent floods. Yet the elimination of mortality in wild populations caused by catastrophic events is not possible. The minimization of losses and better understanding of the magnitude of mortality and its real effect on populations are tasks for future research.

Acknowledgments We are grateful to the Forest Inspectorates of Kędzierzyn-Koźle, Strzelce Opolskie, Krasiejów, Opole, Kup, Brzeg, Oława, Oborniki Śląskie, Miękinia and Wołów, as well as to the Regional Boards of the Polish Hunting Association in Wrocław and Opole for making the data of post-flood survey and results of game monitoring available to us. This article was improved by suggestions from Prof. Henryk Okarma, and two anonymous reviewers. We are also grateful to Michael Lee for linguistic help.

Open Access This article is distributed under the terms of the Creative Commons Attribution License which permits any use, distribution, and reproduction in any medium, provided the original author(s) and the source are credited.

\section{References}

Andersen DC, Wilson KR, Miller MS, Falck M (2000) Movement patterns of riparian small mammals during predictable floodplain inundation. J Mammal 81:1087-1099

Anthony RG, O'Connell MA, Pollock MM, Hallett JG (2003) Associations of mammals with riparian ecosystems in Pacific Northwest forests. In: Zabel CJ, Anthony RG (eds) Mammal community dynamics: management and conservation in the coniferous forests of western North America. Cambridge University Press, Cambridge, pp 510-563

Ballinger A, Mac Nally R, Lake PS (2005) Immediate and longer-term effects of managed flooding on floodplain invertebrate assemblages in south-eastern Australia: generation and maintenance of a mosaic landscape. Freshw Biol 50(7):1190-1205

Bateman HL, Harner MJ, Chung-MacCoubrey A (2008) Abundance and reproduction of toads (Bufo) along a regulated river in the southwestern United States: importance of flooding in riparian ecosystems. J Arid Environ 72:1613-3232

Bennetts RE, Kitchens WM, Dreitz VJ (2002) Influence of an extreme high water event on survival, reproduction, and distribution of Snail Kites in Florida, USA. Wetlands 22:366-739

Bobek B, Morow K, Perzanowski K, Kosobucka M (1992) Jeleń. Monografia przyrodniczo-łowiecka. Wydawnictwo Świat, Warszawa

Boon PJ, Davies BR, Petts GE (2000) Global perspectives on river conservation: science, policy and practice. Wiley, Chichester

Breck SW, Wilson KR, Andersen DC (2001) The demographic response of bank-dwelling beavers to flow regulation: a comparison on the Green and Yampa rivers. Can J Zool 79:1957-3921

Bunn SE, Arthington AH (2002) Basic principles and ecological consequences of altered flow regimes for aquatic biodiversity. Environ Manage 30(4):492-507

Dubicki A, Słota H, Zieliński H (1999) Dorzecze Odry. Monografia powodzi lipiec 1997. Institute of Meteorology and Water Management, Warszawa

Ericsson G, Wallin K (1999) Hunter observations as an index of moose Alces alces population parameters. Wildlife Biol 5:177-185

Finkelstein ME, Wolf S, Goldman M, Doak DF, Sievert PR, Balogh G, Hasegawa H (2010) The anatomy of a (potential) disaster: volcanoes, behavior, and population viability of the short-tailed albatross (Phoebastria albatrus). Biol Conserv 143(2):321-331

Franssen NR, Gido KB, Guy CS, Tripe JA, Shrank SJ, Strakosh TR, Bertrand KN, Franssen CM, Pitts KL, Paukert CP (2006) Effects of floods on fish assemblages in an intermittent prairie stream. Freshw Biol 51(11):2072-2086

Fruziński B (1992) Dzik. Wydawnictwo Cedrus, Warszawa 
Fruziński B (2002) Gospodarka łowiecka. Wydawnictwo Łowiec Polski, Warszawa

García P (2009) Mortality of vertebrates in irrigation canals in an area of west-central Spain. Anim Biodivers Conserv 32(2):123-126

Gerisch M, Dziock F, Schanowski A, Ilg C, Henle K (2012) Community resilience following extreme disturbances: the response of ground beetles to a severe summer flood in a Central European lowland stream. River Res Appl 28:81-92

Gittleman JL (1996) Carnivore behavior, ecology, and evolution. Comstock Pub Associates

Goszczyński J (1995) Lis. Monografia przyrodniczo-łowiecka. Oikos, Warszawa

Heinen JT, Singh GR (2001) A census and some management implications for wild buffalo (Bubalus bubalis) in Nepal. Biol Conserv 101:391-785

Holmgren M, Stapp P, Dickman CR, Gracia C, Graham S, Gutiérrez JR, Hice C, Jaksic F, Kelt DA, Letnic M (2006) Extreme climatic events shape arid and semiarid ecosystems. Front Ecol Environ 4:87-182

Humphries P, King AJ, Koehn JD (1999) Fish, flows and flood plains: links between freshwater fishes and their environment in the Murray-Darling River system, Australia. Environ Biol Fishes 56:129-280

Jacob J (2003) The response of small mammal populations to flooding. Mamm Biol 68:102-213

Jacobs J (1974) Quantitative measurement of food selection. Oecologia 14:413-830

Jakubiec Z, Wuczyński A (2002) Próba ustalenia wpływu powodzi w 1997 roku na wybrane gatunki zwierząt łownych w dolinie środkowej Odry. In: Denisiuk Z (ed) Strategia zachowania różnorodności biologicznej i krajobrazowej obszarów przyrodniczo cennych dotkniętych klęską powodzi. Instytut Ochrony Przyrody PAN, Kraków, pp 132-140

Jankowski W, Świerkosz K (eds) (1995) Oder as an ecological corridor. State-Functioning-Threats. Fundacja IUCN Poland, Warszawa

Jonkman SN (2008) Global perspectives on loss of human life caused by floods. Nat Hazards 34:151-175

Krupka J (1989) Łowiectwo. PWRiL, Warszawa

Kundzewicz ZW (2005) Intense precipitation and high river flows in Europe - observations and projections. Acta Geophys Pol 53:385

Kundzewicz ZW, Schellnhuber HJ (2004) Floods in the IPCC TAR perspective. Nat Hazards 31:111-239

Kundzewicz ZW, Szamalek K, Kowalczak P (1999) The great flood of 1997 in Poland. Hydrol Sci J 44:855-1725

Lada H, Thomson J, Mac Nally R, Horrocks G, Taylor A (2007) Evaluating simultaneous impacts of three anthropogenic effects on a floodplain-dwelling marsupial Antechinus flavipes. Biol Conserv 134(4):527-536

Loveridge AJ, Reynolds JC, Milner-Gulland E (2006) Does sport hunting benefit conservation? In: Macdonald DW, Service K (eds) Key topics in conservation biology. Blackwell Publishing Ltd., Oxford, pp 222-238

Lytle DA, Poff NL (2004) Adaptation to natural flow regimes. Trends Ecol Evol 19(2):94-100

McKechnie AE, Wolf BO (2009) Climate change increases the likelihood of catastrophic avian mortality events during extreme heat waves. Biol Lett 6(2):253-256

Newton I (1998) Population limitation in birds. Academic Press, London

Ogielska M, Kazana K, Pałczyński M, Tomaszewska A (1999) An influence of the great flood 1997 on the amphibian and reptilian populations in the Odra river valley near Wroclaw (Lower Silesia, Poland). In: Miaud C, Guetant R (eds) Current studies in herpetology. Societas Europaea Herpetologica, Le Bourget du Lac, pp 319-642

Okarma H, Tomek A (2008) Łowiectwo. Wydawnictwo Edukacyjno-Naukowe $\mathrm{H}_{2} \mathrm{O}$, Kraków

Palmer MA, Reidy Liermann CA, Nilsson C, Flörke M, Alcamo J, Lake PS, Bond N (2008) Climate change and the world's river basins: anticipating management options. Front Ecol Environ 6(2): 81-89

Paredes-Arquiola J, Martinez-Capel F, Solera A, Aguilella V (2011) Implementing environmental flows in complex water resources systems-case study: the Duero river basin. Spain, River Res Appl

Parmesan C, Root TL, Willig MR (2000) Impacts of extreme weather and climate on terrestrial biota. Bull Am Meteorol Soc 81:443-450

Pedroli B, de Blust G, van Looy K, van Rooij S (2002) Setting targets in strategies for river restoration. Landsc Ecol 17:5-23

Peris S, Morales J (2004) Use of passages across a canal by wild mammals and related mortality. Eur J Wildl Res 50(2):67-72

Pielowski Z (1988) Sarna. PWRiL, Warszawa

Poff NLR, Allan JD, Palmer MA, Hart DD, Richter BD, Arthington AH, Rogers KH, Meyer JL, Stanford JA (2003) River flows and water wars: emerging science for environmental decision making. Front Ecol Environ 1:298-604

Poiani A (2006) Effects of floods on distribution and reproduction of aquatic birds. Adv Ecol Res 39:63-83 
Profus P (2002) Ocena wpływu wysokich opadów i powodzi na wybrane populacje kręgowców. In: Denisiuk Z (ed) Strategia zachowania różnorodności biologicznej i krajobrazowej obszarów przyrodniczo cennych dotkniętych klęską powodzi. Instytut Ochrony Przyrody PAN, Kraków, pp 107-115

Pucek Z, Bobek B, Labudzki L, Milkowski L, Morow K, Tomek A (1975) Estimates of density and number of ungulates. Pol Ecol Stud 1:121-257

Ranta E, Kaitala V, Lundberg P (2006) Ecology of populations. Cambridge University Press, Cambridge

Robinson C, Tockner K, Ward J (2002) The fauna of dynamic riverine landscapes. Freshw Biol 47: $661-1338$

Romanowski J (2007) Vistula river valley as the ecological corridor for mammals. Pol J Ecol 55:805-819

Sabo JL, Sponseller R, Dixon M, Gade K, Harms T, Heffernan J, Jani A, Katz G, Soykan C, Watts J, Welter J (2005) Riparian zones increase regional species richness by harboring different, not more, species. Ecology 86(1):56-62

Schinegger R, Trautwein C, Melcher A, Schmutz S (2012) Multiple human pressures and their spatial patterns in European running waters. Water Environ J 26(2):261-273

StatSoft Inc. (2010) STATISTICA (data analysis software system), version 9.1. [cited 2011 September 5]. Available from: www.statsoft.-com

Stickel LF (1948) Observations on the effect of flood on animals. Ecology 29(4):505-507

Thibault KM, Brown JH (2008) Impact of an extreme climatic event on community assembly. Proc Natl Acad Sci 105(9):3410-3415

Tomiałojć L (ed) (1993) Nature and environment conservation in the lowland river valleys of Poland. Instytut Ochrony Przyrody PAN, Kraków

Tryjanowski P, Sparks TH, Profus P (2009) Severe flooding causes a crash in production of white stork (Ciconia ciconia) chicks across Central and Eastern Europe. Basic Appl Ecol 10(4):387-392

Vörösmarty CJ, McIntyre PB, Gessner MO, Dudgeon D, Prusevich A, Green P, Glidden S, Bunn SE, Sullivan CA, Liermann CR, Davies PM (2010) Global threats to human water security and river biodiversity. Nature 467:555-561

Ward J, Tockner K, Arscott D, Claret C (2002) Riverine landscape diversity. Freshw Biol 47:517-539

Ważna A, Gabryś G (1998) The population of the Eurasian beaver Castor fiber Linnaeus, 1758 in the Wrocław province after the flood of July 1997. Roczniki Muzeum Górnoślasskiego (Przyroda) 15: 181-194

Welbergen JA, Klose SM, Markus N, Eby P (2008) Climate change and the effects of temperature extremes on Australian flying-foxes. Proc R Soc Lond Ser B Biol Sci 275:419-425

Wijnhoven S, van der Velde G, Leuven RSEW, Smits AJM (2006) Modelling recolonisation of heterogeneous river floodplains by small mammals. Hydrobiologia 565:135-152

Williams AK, Ratnaswamy MJ, Renken RB (2001) Impacts of a flood on small mammal populations of lower Missouri River floodplain forests. Am Midl Nat 146:217-438

Yeager LE, Anderson HG (1944) Some effects of flooding and waterfowl concentration on mammals of a refuge area in central Illinois. Am Midl Nat 31:159-178 